\title{
Impact of Nisin Producing Culture and Liposome-encapsulated Nisin on Ripening of Lactobacillus added-Cheddar Cheese
}

\author{
R.-O. Benech*, E. E. Kheadr*†, C. Lacroix*, and I. Fliss* \\ ${ }^{*}$ Dairy Research Centre STELA, Pavillon Paul Comtois, Université Laval, Québec, PQ, Canada, G1K7P4 \\ †Department of Dairy Science and Technology, Faculty of Agriculture, University of Alexandria, Alexandria, Egypt
}

\begin{abstract}
This study aimed to evaluate the effects of incorporating liposome-encapsulated nisin $\mathrm{Z}$, nisin $\mathrm{Z}$ producing Lactococcus lactis ssp. lactis biovar. diacetylactis UL719, or Lactobacillus casei-casei L2A adjunct culture into cheese milk on textural, physicochemical and sensory attributes during ripening of Cheddar cheese. For this purpose, cheeses were made using a selected nisin tolerant cheese starter culture. Proteolysis, free fatty acid production, rheological parameters and hydrophilic/hydrophobic peptides evolution were monitored over 6 mo ripening. Sensory quality of cheeses was evaluated after 6 mo. Incorporating the nisin-producing strain into cheese starter culture increased proteolysis and lipolysis but did not significantly affect cheese rheology. Liposome-encapsulated nisin did not appear to affect cheese proteolysis, rheology and sensory characteristics. The nisinogenic strain increased the formation of both hydrophilic and hydrophobic peptides present in the cheese water extract. Sensory assessment indicated that acidic and bitter tastes were enhanced in the nisinogenic strain-containing cheese compared to control cheese. Incorporating $L b$. casei and the nisinogenic culture into cheese produced a debittering effect and improved cheese flavor quality. Cheeses with added $L b$. casei and liposome-encapsulated nisin $\mathrm{Z}$ exhibited the highest flavor intensity and were ranked first for sensory characteristics.
\end{abstract}

(Key words: nisin Z, liposome, secondary microflora, ripening)

\section{INTRODUCTION}

Food preservation and microbiological quality represent major preoccupations and challenges to food manufacturers. Lactic acid bacteria and their metabolites have been shown to play an important role in improving microbiological quality and shelf life of many fer-

Received November 14, 2002.

Accepted January 10, 2003.

Corresponding author: I. Fliss; e-mail: ismail.fliss@aln.ulaval.ca. mented food products and provide a good example of biopreservation (Zottola et al., 1994). These organisms are able to produce a wide variety of antimicrobial compounds including proteinaceous substances called bacteriocins. The bacteriocin, nisin, produced by strains of Lactococcus lactis, has received particular attention because of its large inhibitory effect against a wide variety of Gram-positive organisms (Rodriguez, 1996). Nisin is the only bacteriocin Generally Recognized as Safe (GRAS), and the World Health Organization (Hurst, 1981) has approved its use as a food additive.

Several forms of concentrated nisin are now commercially produced and routinely used as a food additive in products such as pasteurized cheese spreads, sauces and salad dressings (Mazzotta et al., 1997). In the cheese industry, the use of nisin in free form, such as Nisaplin (Aplin and Barret, Ltd), is costly and has drawbacks, including lower activity, stability, and bioavailability (Roberts and Zottola, 1993). Moreover, free nisin may interfere with cheese-making process or reduce cheese quality by inhibiting the starter culture or nonstarter lactic acid bacteria important in ripening and flavor development (Buyong et al., 1998). There has thus been continued interest in developing other means of incorporating nisin into cheese, such as the use of a mixed starter culture containing a nisinproducing strain (Maisner-Patin et al., 1992). Since most starter cultures show variable sensitivity to nisin (Rada and Dlabal, 1998), nisin-producing strains should be combined with nisin resistant or tolerant starter culture to ensure a proper balance between lysed and intact cells (Benech et al., 2002a).

Microencapsulated nisin has proven to be a powerful inhibitor of pathogens and spoilage organisms in cheese without disrupting the cheese-making process and could thus act as a long-term preservative in cheese (Benech et al., 2002a). Laridi et al. (2003) have optimized the encapsulation of nisin $\mathrm{Z}$ in liposomes prepared from proliposomes. The stability and efficacy of this system at inhibiting Listeria innocua during Cheddar cheese ripening has been evaluated by Benech et al. 2002a who showed that liposome-entrapped nisin $\mathrm{Z}$ was much more effective at reducing viable 
counts of $L$. innocua than nisin-producing mixed culture. Liposome-encapsulated nisin was also more stable, retaining $90 \%$ of its initial activity after 6 mo of ripening.

Cheese starters have been shown to play an important role in cheese ripening by producing several proteases and peptidases, which collectively degrade large casein-derived peptides to amino acids (Fox, 1989). Most of these enzymes are intracellular and are released for activity in cheese only upon cell autolysis (Tan et al., 1992). In addition to its effectiveness at reducing the viability of Gram-positive pathogens and spoilage bacteria in cheese, nisin induces lysis of starter releasing intracellular enzymes and thus accelerating casein hydrolysis and associated flavor development (Morgan et al., 1997). We have previously studied the lytic action of nisin Z, either produced in situ by Lactococcus lactis ssp. lactis biovar diacetylactis UL719 or encapsulated in liposomes, against nisinsensitive subpopulations of lactococci and Lactobacillus casei-casei L2A during ripening of Cheddar cheese (Benech et al., 2002a). In the present study we evaluate the effects of incorporating liposome-encapsulated nisin Z, Lactococcus lactis ssp. lactis biovar. diacetylactis UL719 or Lactobacillus casei-casei L2A on textural, physicochemical and sensory attributes during ripening of Cheddar cheese.

\section{MATERIALS AND METHODS}

\section{Bacteria and Growth Conditions}

Lactococcus lactis ssp. lactis biovar. diacetylactis UL719 (Lac. diacetylactis UL719) was used as the nisin Z-producing strain. Lactococcus lactis ssp. cremoris $\mathrm{KB}$ (Lac. cremoris $\mathrm{KB}$ ) and Lactococcus lactis ssp. lactis $\mathrm{KB}$ (Lac. lactis $\mathrm{KB}$ ) were obtained from (Ezal, Rhône Poulenc, Mississauga, ON, Canada). A commercial cheese mixed set culture (No. 911) from Chr. Hansen (Milwaukee, WI) was used as a commercial reference starter. Lactobacillus casei-casei L2A (Lb. casei) from our culture collection was used as secondary flora. Pediococcus acidilactici UL5, from our collection, was used as the indicator organism for the bacteriocin activity assay (Benech et al., 2002a).

All pure cultures were maintained in $20 \%$ glycerol stock at $-80^{\circ} \mathrm{C}$ and the commercial set culture (No. 911) was kept at $-20^{\circ} \mathrm{C}$ as recommended by the manufacturer. Strains of Lactococcus sp. were grown in M17 broth medium (BDH-Merck, Darmstadt, Germany) supplemented with $0.5 \%$ (wt/vol) glucose and incubated overnight at $30^{\circ} \mathrm{C}$. Lac. diacetylactis UL719 was grown in MRS broth obtained from Institut Rosell Inc. (Montreal, QC, Canada) and incubated overnight at $30^{\circ}$ C. Lb. casei was reactivated in MRS broth and incu- bated anaerobically in Oxoid jars using an atmosphere generation system (Oxoid anaeroGen, Oxoid Ltd., Basingstoke, Hampshire, England) at $37^{\circ} \mathrm{C}$. Prior to beginning the experiments, each bacterial strain was subcultured at least three times $(1 \%, \mathrm{vol} / \mathrm{vol})$ in the indicated medium at $24 \mathrm{~h}$ intervals.

\section{Nisin Z Production and Purification}

Nisin $\mathrm{Z}$ was extracted from an overnight culture of Lac. diacetylactis UL719 in MRS broth and purified using an immunoaffinity column developed in our laboratory as previously described (Benech et al., 2002a). Nisin $\mathrm{Z}$ activity was determined by agar diffusion and competitive enzyme immunoassays (c-EIA) and purity was tested by the HPLC method described previously by Daoudi et al. (2001).

\section{Liposome Preparation}

Liposomes were prepared from proliposome H (Prolipo $\mathrm{H}$ ), a food-grade hydrogenated phosphatidylcholine obtained from Lucas Meyer (Chelles, France). For cheese production, $5 \mathrm{~g}$ of Pro-lipo $\mathrm{H}$ were converted to liposomes by mixing them with $5 \mathrm{ml}$ aqueous nisin solution $(5 \mathrm{mg} / \mathrm{ml})$. The vesicles formed were thus separated from unencapsulated nisin, washed and resuspended in deionized water following the procedure previously described (Laridi et al., 2003). The amount of encapsulated and unencapsulated nisin was determined using c-EIA and agar diffusion methods (Daoudi et al., 2001).

\section{Cheese-making Procedure}

A previously optimized cheese starter composed of Lac. lactis $(\mathrm{KB})$ and Lac. cremoris $(\mathrm{KB})(1: 1, \mathrm{vol} / \mathrm{vol})$ was selected for its high acidifying capacity and nisin $\mathrm{Z}$ tolerance (Benech et al., 2002a). Nisin-producing mixed starter was composed of cheese starter and Lac. diacetylactis UL719 culture at a ratio of 3:1 ( $\mathrm{vol} / \mathrm{vol}$ ), respectively. For secondary flora, $L b$. casei L2A was added to cheese milk at a level of $10^{3}-10^{4} \mathrm{cfu} / \mathrm{ml}$ simultaneously with the starter culture. The commercial mixed set culture (No. 911) was used as a reference. Lactococcus strains and $L b$. casei were grown separately in sterilized reconstituted skim milk (11\% total solids) and incubated overnight at $30^{\circ} \mathrm{C}$ and $37^{\circ} \mathrm{C}$, respectively. The experimental cheeses and their codes are given in Table 1.

Prior to cheese-making, cheese milk was standardized to a constant fat content of $3.4 \%$, pasteurized at $72^{\circ} \mathrm{C}$ for 16 seconds $\left(80^{\circ} \mathrm{C} / 16\right.$ seconds for $\mathrm{Lb}$. caseicontaining cheese milk) and cooled to $4^{\circ} \mathrm{C}$. Milk was 
Table 1. Cheese treatments made in this study.

\begin{tabular}{|c|c|c|c|c|}
\hline Cheese code ${ }^{1}$ & $\begin{array}{l}\text { Commercial cheese } \\
\text { mixed set culture } \\
\text { (No. 911) }\end{array}$ & $\begin{array}{l}\text { Lac. diacetylactis } \\
\text { UL7 } 79^{2}\end{array}$ & $\begin{array}{l}\text { Encapsulated } \\
\text { nisin } Z^{3}\end{array}$ & $\begin{array}{l}\text { Lb. casei } \\
\text { L2A }\end{array}$ \\
\hline $\mathrm{COM}$ & + & - & - & - \\
\hline In situ nisin-containing cheese (ISN) & - & + & - & - \\
\hline Nisin free cheese added with $L b$. casei (NFB) & - & - & - & + \\
\hline In situ nisin-containing cheese added with $L b$. casei (ISNB) & - & + & - & + \\
\hline Liposome nisin-containing cheese added with Lb. casei (LNB) & - & - & + & + \\
\hline
\end{tabular}

${ }^{1}$ All cheeses, except for COM-cheese, were made using a 1:1 (vol/vol) mixed starter culture of Lactococcus lactis subsp. lactis (KB) and Lactococcus lactis subsp. cremoris (KB), added or not with Lactobacillus casei L2A (B) at level of 1-10 $\times 10^{3} \mathrm{CFU} / \mathrm{ml}$.

${ }^{2} \mathrm{Nisin}$ Z-producing strain: Lactococcus lactis ssp. lactis biovar. diacetylactis UL719 (Lac. diacetylactis UL719).

${ }^{3} \mathrm{Nisin}$ encapsulated liposomes were produced by diluting $5 \mathrm{~g}$ of proliposome $\mathrm{H}$ with $5 \mathrm{ml}$ of nisin $\mathrm{Z}$ aqueous solution of $5 \mathrm{mg} / \mathrm{ml}$. Following separation of liposomes, the resulting vesicles were added to $10 \mathrm{~L}$ cheese milk for a final concentration of $300 \mathrm{IU} / \mathrm{g}$ cheese.

- and + absence or presence.

then warmed up to $32^{\circ} \mathrm{C}$ and inoculated with the selected cheese mixed starter culture at $1.5 \%$ (vol/vol), or with the commercial starter (No. 911) using $6 \mathrm{ml}$ of freeze-concentrated culture in $10 \mathrm{~L}$ vat as recommended by the manufacturer to produce Cheddar cheese following the standard procedure as described previously (Kosikowski, 1982). Milk was ripened until the $\mathrm{pH}$ reached 6.5 (approximately $45 \mathrm{~min}$ ) and liposomes containing nisin $\mathrm{Z}$ were added 5 min before rennet addition. Calcium chloride was added at a ratio of $0.02 \%$ (wt/vol). Milk was coagulated at $32^{\circ} \mathrm{C}$ in 30 min using rennet Chy-Max extra from Chr. Hansen (Milwaukee, WI). The coagulum was cut and the temperature was slowly raised to $39^{\circ} \mathrm{C}$ to induce syneresis and to increase curd firmness. Whey was drained and the curd was subjected to cheddaring process for 120 min at $36^{\circ} \mathrm{C}$, until the $\mathrm{pH}$ reached $5.3 \pm 0.1$, milled, dry-salted $(2.0 \%$ salt, wt/wt), transferred in a round mold and pressed overnight. Following pressing, the $1 \mathrm{~kg}$-cheese blocks were cut and a representative sample of approximately $200 \mathrm{~g}$ was taken for proximate and microbiological analyses. Cheese blocks were then vacuum-packed in plastic bags (4-mil thickness, Winpax Co., Winnipeg, MB, Canada), coded and ripened at $7^{\circ} \mathrm{C}$ for $6 \mathrm{mo}$.

\section{Cheese Analysis}

Analyses were performed in duplicate unless otherwise stated. Moisture, total nitrogen, (TN) and ash content were determined by the AOAC method (1990). Fat content was determined by the Babcock-fat test described by Bartels et al. (1987). For pH measurement, about $20 \mathrm{~g}$ of the cheese sample were soften by mixing them with the same amount of deionized water previously warmed at $40^{\circ} \mathrm{C}$ and the whole mixture was kept for 5 minutes at room temperature. The $\mathrm{pH}$ was then measured using a Spear Tip combination electrode (VWR Scientific, Ville Mont-Royal, QC, Canada).

\section{Microbiological Analyses}

Samples of $10 \mathrm{~g}$ were taken in triplicate and homogenized for 3 min with $90 \mathrm{ml}$ of sterile $2 \%$ sodium citrate in a Stomacher (Lab Blender 80; Seward Medical, London, UK). Samples were then serially diluted 10 -fold using $2 \%$ sodium citrate. Appropriate dilutions were plated on lactococcus selective media named Kempler and McKay agar (KMK) and incubated aerobically at $37^{\circ} \mathrm{C}$ for $24 \mathrm{~h}$ to enumerate lactococci (Kempler and McKay, 1980). Lb. casei was enumerated by plating appropriate dilutions on acidified MRS agar ( $\mathrm{pH}$ 5.6) and incubating anaerobically at $37^{\circ} \mathrm{C}$ for $72 \mathrm{~h}$.

\section{Cheese Proteolysis}

Fat-free cheese homogenates were prepared according to the method of Kuchroo and Fox (1982). Water-soluble nitrogen (WSN) was determined by the Kjeldahl method (IDF, 1993). Trichloroacetic acid-soluble nitrogen (TCA-SN) was determined according to the method of Kuchroo and Fox (1982) and phosphotungstic acid-soluble nitrogen (PTA-SN) was determined according to the method of Gripon et al. (1975).

\section{Nisin Activity Determination}

Nisin $\mathrm{Z}$ extraction from the cheese matrix and the agar diffusion test used to determine nisin activity were performed as previously described (Benech et al., 2002a).

\section{Textural Measurement}

Texture profile analyses were performed on cheese samples using the double compression test (TA-XT2 
Texture Analyzer, Texture Technologies, Carry, NY). Ten cylindrical portions ( $1 \mathrm{~cm}$ high and $1 \mathrm{~cm}$ diameter) were removed from the interior of the cheese with a cork borer and held at room temperature for one hour before testing. Samples were compressed to $80 \%$ of their original height and the compression speed was set at $2 \mathrm{~cm} / \mathrm{min}$. The following parameters were evaluated according to the definitions given by the International Dairy Federation (1991): Fracturability (N): The force at which the material fractures; Cohesiveness (no dimension): The quantity to simulate the strength of the internal bonds making up the body of the product.

\section{Reversed-Phase High Performance Liquid Chromatography}

The water-soluble nitrogen extract (WSNE) of experimental cheeses was prepared as described above following the method of Kuchroo and Fox (1982) and freeze-dried. Prior to HPLC analysis, $1.0 \mathrm{~g}$ of the freeze-dried WSNE was dissolved in $10 \mathrm{ml}$ HPLC grade water. The mixture was then stirred for $30 \mathrm{~min}$ at room temperature, filtered through a $0.20 \mu \mathrm{m}$ filter (Nalge Co., Rochester, NY, USA) and stored at $-20^{\circ} \mathrm{C}$ in a 2-ml vial until analysis (Lau et al., 1991). The HPLC analysis was carried out using a Waters HPLC system (Waters Limited, Mississauga, ON, Canada) consisting of a controller (Waters model 600), four solvent pumps (Waters model $60 \mathrm{~F}$ ), a $100 \mu \mathrm{l}$ sample loop, a wavelength monitor (Waters Model 486), an autosampler (Waters Model 717), and an integrator (Millenium $^{32}$, version 3.20, PC Waters). Samples were analyzed using a $4.6 \mathrm{~mm} \times 250 \mathrm{~mm}, \mathrm{C}_{18}$ MC $120(10$ $\mu \mathrm{m}$ mesh size) reversed-phase column (Phenomenex, Torrance, CA). The column was equilibrated at room temperature with $0.5 \%(\mathrm{vol} / \mathrm{vol})$ trifluoroacetic acid (TFA, Sigma Chemical Co., St Louis, MO) followed by sample injection. A sample volume of 20 and $80 \mu \mathrm{l}$ was injected into the column for runs at 214 and $280 \mathrm{~nm}$, respectively. Peptides were eluted with a linear solvent gradient from $0.5 \%$ ( $\mathrm{vol} / \mathrm{vol}$ ) TFA in water to $0.035 \%$ (vol/vol) TFA in 90:10 (vol/vol) acetonitrile:water. Run time was $30 \mathrm{~min}$ and flow rate was $1 \mathrm{ml} /$ min. The WSNE of each cheese, at $0 \mathrm{~d}$ (samples taken immediately after the pressing step) and at 2,4 , and 6 mo of ripening, was analyzed by RP-HPLC with detection at wavelengths of 214 and $280 \mathrm{~nm}$.

Water and acetonitrile were of HPLC grade and TFA was protein-sequencing grade. Solvents were filtered on Nylaflo membrane disc filters (VWR, Ville MontRoyal, QC, Canada) with a pore size of $0.2 \mu \mathrm{m}$, sparged with helium for $30 \mathrm{~min}$, and blanketed with helium during storage. The UV absorption peaks with reten- tion times from 9.9 to $14.9 \mathrm{~min}$ at $214 \mathrm{~nm}$ and from 7.3 to $14.9 \mathrm{~min}$ at $280 \mathrm{~nm}$ correspond to hydrophilic peptides. Peaks with retention times from 14.9 to 20.8 min at both wavelengths were considered hydrophobic.

\section{Sensory Evaluation}

Sensory quality of cheeses was evaluated after 6 mo of ripening using a five-point hedonic scale. The panelists were from the Sensory Evaluation Interest Group of the Food Research and Development Center (Agriculture and Agri-Food Canada, Ste Hyacinthe, $\mathrm{PQ}$, Canada). Panelists $(\mathrm{n}=5)$ had prior training and experience in evaluating the sensory quality of Cheddar cheese. Cheese samples were coded with random 4-digit numbers and approximately $100 \mathrm{~g}$ of cheese was partitioned into $5 \mathrm{~g}$ cubes. Coded samples were removed from the refrigerator $\left(7^{\circ} \mathrm{C}\right) 1 \mathrm{~h}$ prior to evaluation, kept at room temperature $\left(22 \pm 1^{\circ} \mathrm{C}\right)$, and presented to the panelists. Panelists evaluated cheese for texture, flavor, and overall quality. Each cheese was evaluated in triplicate by each panelist.

\section{Statistical Analysis}

All experimental cheese-making treatments were performed in triplicate and all analyses were done in duplicate. For statistical analyses, cheeses were divided into two groups, the first including $L b$. casei-free cheeses subjected to treatments NF, ISN and COM and the second including $L b$. casei-containing cheeses subjected to treatments NFB, ISNB and LNB. All statistical analyses were performed with Stat View SE + Graphics (Abacus Concepts, Inc., Berkeley, CA). Significant differences between treatments were tested by analysis of variance (ANOVA). Treatment comparisons were performed using Fisher's protected least significant difference (PLSD) test. The level of significance was $P<0.05$.

\section{RESULTS AND DISCUSSION}

\section{Cheese Composition}

Cheese gross composition, determined as wet weight, on the day of manufacture, with respect to moisture, fat and protein content, did not significantly differ within the same group. Moisture, fat and protein contents in $L b$. casei-free cheese were, respectively, $37.3 \pm 0.3 \%, 32.0 \pm 0.3 \%$ and $23.6 \pm 0.2 \%$. Moisture content in cheeses with added $L b$. casei subjected to treatments NFB and ISNB was $38.5 \pm 0.2 \%$. The higher moisture content in cheeses with $L b$. casei may be attributed to increased incorporation of heat denaturated whey proteins into the cheese curd, resulting in 
Table 2. Nisin activity, titratable acidity and acid value of experimental cheeses.

\begin{tabular}{|c|c|c|c|c|}
\hline Cheese $^{1}$ & $\begin{array}{l}\text { Ripening } \\
\text { stage } \\
\text { (mo) }\end{array}$ & $\begin{array}{l}\text { Nisin } \\
\text { activity } \\
\text { (IU/g) }\end{array}$ & $\begin{array}{l}\text { Titratable } \\
\text { activity } \\
(\%)\end{array}$ & $\begin{array}{l}\text { Acid value } \\
\left(\mathrm{mg} \mathrm{KOH} / \mathrm{g} \text { cheese }{ }^{2}\right)\end{array}$ \\
\hline \multicolumn{5}{|c|}{ Lb. casei-free cheese } \\
\hline \multirow[t]{2}{*}{$\mathrm{COM}$} & 0 & - & $0.864 \pm 0.018^{\mathrm{c}}$ & $0.495 \pm 0.001^{\mathrm{f}}$ \\
\hline & 6 & - & $1.20 \pm 0.021^{b}$ & $1.980 \pm 0.071^{\mathrm{b}}$ \\
\hline \multirow[t]{2}{*}{ NF } & 0 & - & $0.882 \pm 0.031^{\mathrm{c}}$ & $0.630 \pm 0.001^{\mathrm{e}}$ \\
\hline & 6 & - & $1.188 \pm 0.036^{\mathrm{b}}$ & $1.305 \pm 0.001^{\mathrm{c}}$ \\
\hline \multirow[t]{2}{*}{ ISN } & 0 & $308 \pm 18^{\mathrm{a}}$ & $0.816 \pm 0.01^{\mathrm{c}}$ & $0.810 \pm 0.010^{\mathrm{d}}$ \\
\hline & 6 & $35 \pm 2.0^{b}$ & $1.51 \pm 0.036^{\mathrm{a}}$ & $2.475 \pm 0.035^{\mathrm{a}}$ \\
\hline \multicolumn{5}{|c|}{ Lb. casei-containing cheese } \\
\hline \multirow[t]{2}{*}{ NFB } & 0 & - & $0.768 \pm 0.027^{\mathrm{c}}$ & $0.495 \pm 0.001^{\mathrm{c}}$ \\
\hline & 6 & - & $1.20 \pm 0.027^{\mathrm{b}}$ & $1.283 \pm 0.018^{\mathrm{c}}$ \\
\hline \multirow[t]{2}{*}{ ISNB } & 0 & $301 \pm 14^{\mathrm{a}}$ & $0.792 \pm 0.027^{\mathrm{c}}$ & $0.855 \pm 0.035^{\mathrm{d}}$ \\
\hline & 6 & $37 \pm 2.0^{\mathrm{b}}$ & $1.346 \pm 0.027^{\mathrm{a}}$ & $2.925 \pm 0.035^{\mathrm{b}}$ \\
\hline \multirow[t]{2}{*}{ LNB } & 0 & $286 \pm 12^{\mathrm{a}}$ & $0.786 \pm 0.010^{c}$ & $0.495 \pm 0.001^{\mathrm{e}}$ \\
\hline & 6 & $267 \pm 14^{\mathrm{a}}$ & $1.182 \pm 0.036^{\mathrm{b}}$ & $3.240 \pm 0.071^{\mathrm{a}}$ \\
\hline
\end{tabular}

a,b,c Means in the same column for the same group of cheese with different superscripts are significantly different $(P<0.05)$.

${ }^{1}$ Cheese made with commercial cheese mixed set culture (COM), Nisin free cheese (NF), In situ nisincontaining cheese (ISN), Nisin free cheese added with $L b$. casei (NFB), In situ nisin-containing cheese added with $L b$. casei (ISNB), Liposome nisin-containing cheese added with Lb. casei (LNB).

${ }^{2}$ Lyophilized cheese.

additional water retention. Meanwhile, cheese made with $L b$. casei and liposome-encapsulated nisin Z (LNB) had a significantly higher moisture content $(39.9 \pm 0.2 \%)$ compared to cheeses receiving treatments NFB and ISNB. An increase in moisture content in liposome-supplemented cheeses has been reported previously and attributed to water binding to the surface of the liposome membrane (Kheadr et al., 2002). Protein and fat did not significantly differ among $L b$. casei-containing cheeses and represented $23.8 \pm 0.2 \%$ and $32.2 \pm 0.3 \%$ respectively of the total mass.

\section{Nisin Activity}

Nisin $\mathrm{Z}$ activity in the Cheddar cheese matrix during ripening is shown in Table 2. Initial nisinogenic activity in cheeses with added strain UL719 (ISN and ISNB cheeses) was $308 \pm 18 \mathrm{IU} / \mathrm{g}$, which dropped to $35 \pm 2$ $\mathrm{IU} / \mathrm{g}$ at $6 \mathrm{mo}$. The Lac. diacetylactis UL719 strain used in this study has been shown to produce 256-512 IU/ $\mathrm{g}$ of nisin $\mathrm{Z}$ in 0 -d-old Gouda cheese, which declined to $32 \mathrm{IU} / \mathrm{g}$ after $27 \mathrm{wk}$ (Bouksaim et al., 2000) possibly due to proteolytic activities of lactic acid bacteria. On the other hand, cheese with added nisin Z-containing liposomes contained $286 \pm 12 \mathrm{IU} / \mathrm{g}$ initially and $267 \pm$ $14 \mathrm{IU} / \mathrm{g}$ at $6 \mathrm{mo}$. The increased stability of nisin Z encapsulated in liposomes compared to that produced in situ by Lac. diacetylactis UL719 has been recently reported (Benech et al., 2002a) and attributed to its maintenance at higher concentration either encapsulated in the internal aqueous phase of the lipid vesicles or immobilized on the lipid membrane. The stability of the nisin-liposome membrane complex during cheese ripening has been demonstrated by immune transmission electron microscopy (Benech et al., 2002b).

\section{Microbiological Analysis}

The initial count of viable lactococci $\left(6.2 \pm 0.5 \times 10^{8}\right.$ $\mathrm{cfu} / \mathrm{g}$ ) did not significantly differ among cheeses (data not shown). During ripening, there was a gradual decrease in all cheeses to $2.8 \pm 0.2 \times 10^{6} \mathrm{cfu} / \mathrm{g}$ at $6 \mathrm{mo}$.

Nisin Z, whether encapsulated or produced in situ by Lac. diacetylactis UL719, did not appear to significantly affect $L b$. casei viable counts after manufacture (data not shown). The initial counts of $L b$. casei were $7.2 \pm 0.5 \times 10^{5} \mathrm{cfu} / \mathrm{g}$, which increased gradually in all cheeses with increasing ripening time. Between 2 and 6 mo, cheeses subjected to treatments ISNB and LNB showed lower viable $L b$. casei counts of 0.2 and 0.5 $\log _{10} \mathrm{cfu} / \mathrm{g}$, respectively, compared with control cheese (NFB). At 6 mo, the viable $L b$. casei counts in NFB cheese reached a level of $7 \log _{10} \mathrm{cfu} / \mathrm{g}$ and counts in cheeses with added liposomes or Lac. diacetylactis UL719 remained significantly inferior by $0.5 \log _{10}$ compared with those in NFB cheese.

\section{Cheese Titratable Acidity}

Initial values for TA and values at 6 mo are presented in Table 2. The TA for cheese made with selected culture (NF) was close to that for cheese made with commercial culture. Values for 0 -d-old ISN cheese were similar to those for $\mathrm{NF}$ and $\mathrm{COM}$ cheeses, but 
became significantly higher at $6 \mathrm{mo}$. Among the $L b$. casei-containing cheeses, ISNB also developed significantly greater acidity at six mo, while no significant difference was observed between LNB cheese and NFB cheese. The increased TA values in nisinogenic straincontaining cheeses were associated with increased production of TCA-SN and PTA-SN. As cheese ages, casein and large peptides are hydrolyzed to low molecular weight water-soluble peptides with titratable carboxyl groups, thus explaining at least part of the increase in TA (Lau et al., 1991).

\section{Lipolysis}

Table 2 shows the acid values (AV) for experimental cheeses. Generally, cheeses with the added nisin-producing strain in both groups (ISN and ISNB cheeses) showed higher acid values than did cheeses without the nisinogenic strain. Higher AVs reported for nisincontaining cheeses may be due to autolysis of nisin sensitive subpopulations of selected lactococci and $L b$. casei and/or to the enzymatic compartment of the nisinogenic strain (Bouksaim et al., 2000). The presence of nisin sensitive subpopulations of the selected lactococci and $L b$. casei used in this study has been previously confirmed with immune transmission electron microscopy (Benech et al., 2002b). The AVs obtained for $L b$. casei-containing cheeses were generally higher than for the $L b$. casei-free group of cheeses. This may be attributable to the enzymatic content of $L b$. casei L2A, which is known to contain several lipases and esterases (El Abboudi, 1990). These enzymes have been shown to produce $\mathrm{C}_{6: 0}$ to $\mathrm{C}_{10: 0}$ fatty acids from which methyl ketones (especially 2-nonanone, 2-heptanone and 2-pentanone) are derived. These methyl ketones have been shown to be essential for Cheddar cheese flavor intensity (El Abboudi, 1990).

\section{Cheese Proteolysis}

The evolution in the amount of TCA-SN and PTASN during ripening of experimental cheeses is given in Table 3. Generally, the amounts of nitrogen soluble in $12 \%$ trichloroacetic acid and 5\% phosphotungstic acid increase with cheese age due to the continued hydrolysis of casein and large peptides to low molecular weight peptides and amino acids by residual rennet and starter culture enzymes (Lau et al., 1991). The amount of TCA-SN did not significantly differ between $\mathrm{NF}$ and $\mathrm{COM}$ cheeses during the ripening period. The TCA-SN content in cheese with the nisinogenic strain (ISN) did not significantly differ from that determined in NF cheese at $0-\mathrm{d}$ and $2 \mathrm{mo}$, but increased at 4 and 6 mo. At 6 mo, ISN cheese accumulated 1.4-fold more
TCA-SN than NF cheese. A similar trend was seen for Lb. casei-containing cheeses, but with a less pronounced effect of the nisin-producing strain. This may be attributed to increased co-precipitation of denatured whey proteins with casein micelles, due to cheese milk pasteurization at high temperature, possibly reducing the accessibility of casein to proteases and peptidases (Lau et al., 1990). Nisin Z-containing liposomes did not appear to affect TCA-SN production.

The amount of PTA-SN in COM cheese was significantly higher than in NF cheese at 6 mo. The ISN cheese contained significantly more PTA-SN at 2, 4, and 6 mo than NF cheese, approximately 1.6 -fold more at 6 mo. Meanwhile, 6-mo-old ISNB-cheese contained 1.4-fold more TCA-SN than NFB cheese, while NFB and LNB cheeses did not differ. PTA-SN measures low molecular weight peptides $(<600 \mathrm{Da})$ and free amino acids (Lin et al., 1987) and has been suggested for monitoring flavor development during ripening of Cheddar cheese (Aston et al., 1983). Extra TCA-SN and PTA-SN production in cheeses with an added nisin-producing strain, as reported herein, should have a significant impact on flavor quality and intensity.

\section{Texture Evaluation}

The changes in rheological characteristics (fracturability and cohesiveness) during ripening of control and experimental cheeses are shown in Table 4 . Among $L b$. casei-free cheeses, ISN cheese exhibited lower initial values for fracturability $(15.9 \pm 1.53 \mathrm{~N})$ than cheese made with selected (NF) or commercial (COM) starter culture $(18.30 \pm 1.50 \mathrm{~N}$ and $20.28 \pm 1.76 \mathrm{~N}$, respectively). There was no such trend among $L b$. casei-containing cheeses. These cheeses showed lower initial values for both parameters, which may be due to the higher thermal treatment temperature applied to milk receiving $L b$. casei, leading to increased incorporation of whey proteins into the cheese matrix and consequently greater water retention in the resulting cheeses. Increased moisture content of cheeses has been shown to be correlated with decreased values for firmness, cohesiveness and fracture force (Kheadr et al., 2002).

On aging, the values for both parameters tended to decrease with the major reduction occurring during the first $2 \mathrm{mo}$ and the process thereafter slowing down. At 2 and $4 \mathrm{mo}$, there were no significant differences between nisin-containing cheeses (ISN, ISNB and LNB) and their corresponding control cheeses (NF and NFB cheese). Decreasing values for fracturability and cohesiveness throughout ripening of Cheddar cheese have been previously reported by Kheadr et al. (2000). 
Table 3. Evolution of total cheese trichloroacetic (TCA-SN) and phosphotungstic acid (PTA-SN) soluble nitrogen.

\begin{tabular}{|c|c|c|c|}
\hline Cheese $^{1}$ & $\begin{array}{l}\text { Ripening stage } \\
\text { (mo) }\end{array}$ & TCA-SN/TN (\%) & PTA-SN/TN (\%) \\
\hline \multicolumn{4}{|c|}{ Lb. casei-free cheese } \\
\hline \multirow[t]{4}{*}{ COM } & 0 & $2.17 \pm 0.12^{\mathrm{g}}$ & $0.811 \pm 0.06^{\mathrm{i}}$ \\
\hline & 2 & $4.90 \pm 0.25^{\mathrm{f}}$ & $1.05 \pm 0.03^{\mathrm{h}}$ \\
\hline & 4 & $6.12 \pm 0.03^{\mathrm{e}}$ & $1.88 \pm 0.01^{\mathrm{e}}$ \\
\hline & 6 & $10.75 \pm 0.04^{\mathrm{bc}}$ & $2.41 \pm 0.04^{\mathrm{c}}$ \\
\hline \multirow[t]{4}{*}{$\mathrm{NF}$} & 0 & $2.32 \pm 0.14^{\mathrm{g}}$ & $0.95 \pm 0.09^{\mathrm{hi}}$ \\
\hline & 2 & $4.93 \pm 0.37^{\mathrm{f}}$ & $1.29 \pm 0.16^{\mathrm{g}}$ \\
\hline & 4 & $6.05 \pm 0.18^{\mathrm{e}}$ & $2.01 \pm 0.01^{\mathrm{de}}$ \\
\hline & 6 & $10.44 \pm 0.13^{\mathrm{c}}$ & $2.16 \pm 0.05^{\mathrm{d}}$ \\
\hline \multirow[t]{4}{*}{ ISN } & 0 & $2.37 \pm 0.05^{\mathrm{g}}$ & $1.09 \pm 0.08^{\mathrm{gh}}$ \\
\hline & 2 & $5.50 \pm 0.57^{\mathrm{ef}}$ & $1.56 \pm 0.11^{\mathrm{f}}$ \\
\hline & 4 & $9.02 \pm 0.20^{\mathrm{d}}$ & $2.87 \pm 0.01^{b}$ \\
\hline & 6 & $14.19 \pm 0.09^{\mathrm{a}}$ & $3.36 \pm 0.01^{\mathrm{a}}$ \\
\hline \multicolumn{4}{|c|}{ Lb. casei-containing cheese } \\
\hline \multirow[t]{4}{*}{ NFB } & 0 & $1.82 \pm 0.08^{\mathrm{f}}$ & $0.75 \pm 0.02^{\mathrm{f}}$ \\
\hline & 2 & $4.85 \pm 0.15^{\mathrm{d}}$ & $1.06 \pm 0.12^{\mathrm{e}}$ \\
\hline & 4 & $6.87 \pm 0.06^{\mathrm{c}}$ & $1.86 \pm 0.02^{\mathrm{d}}$ \\
\hline & 6 & $10.61 \pm 0.34^{\mathrm{b}}$ & $1.98 \pm 0.02^{\mathrm{cd}}$ \\
\hline \multirow[t]{4}{*}{ ISNB } & 0 & $2.03 \pm 0.33^{\mathrm{f}}$ & $0.81 \pm 0.04^{\mathrm{f}}$ \\
\hline & 2 & $4.33 \pm 0.01^{\mathrm{e}}$ & $1.06 \pm 0.04^{\mathrm{e}}$ \\
\hline & 4 & $7.06 \pm 0.06^{\mathrm{c}}$ & $2.00 \pm 0.03^{b c}$ \\
\hline & 6 & $11.22 \pm 0.11^{\mathrm{a}}$ & $2.74 \pm 0.01^{\mathrm{a}}$ \\
\hline \multirow[t]{4}{*}{ LNB } & 0 & $2.04 \pm 0.06^{\mathrm{f}}$ & $0.83 \pm 0.04^{\mathrm{f}}$ \\
\hline & 2 & $4.55 \pm 0.02^{\mathrm{de}}$ & $1.07 \pm 0.03^{\mathrm{e}}$ \\
\hline & 4 & $6.95 \pm 0.04^{\mathrm{c}}$ & $1.98 \pm 0.01^{\mathrm{cd}}$ \\
\hline & 6 & $10.57 \pm 0.06^{\mathrm{b}}$ & $2.03 \pm 0.01^{b c}$ \\
\hline
\end{tabular}

a,b,c,d,e,f,g,h,jMeans in the same column for the same group of cheese with different superscripts are significantly different $(P<0.05)$.

${ }^{1}$ Cheese made with commercial cheese mixed set culture (COM), Nisin free cheese (NF), In situ nisincontaining cheese (ISN), Nisin free cheese added with $L b$. casei (NFB), In situ nisin-containing cheese added with $L b$. casei (ISNB), Liposome nisin-containing cheese added with Lb. casei (LNB).

Six-month-old ISN cheeses tended to be significantly $(P<0.05)$ less fracturable than NF cheese and slightly more cohesive. The higher values for cohesiveness and fracturability appear to be associated with increased PTA-SN production (Table 3). Increased peptidolysis in ISN cheese may have generated small peptides and free amino acids, which have the ability to bind free water, hence the increased strength of the casein matrix (Kheadr et al., 2002). In comparison, values for fracturability and cohesiveness did not significantly $(P<0.05)$ differ among cheeses with $L b$. casei. Values of cohesiveness for LNB cheese in the present study is consistent with that reported by Kheadr et al. (2000) and attributable to increased moisture.

\section{Reversed-Phase High Performance Liquid Chromatography}

The nonvolatile water-soluble fraction is believed to be an essential flavor component of mild and old Cheddar cheese (Aston et al., 1983). HPLC analysis of this fraction has proven valuable for studying the evolution of peptide content and the ratio of hydrophobic:hydro- philic peptides in cheese water-soluble extract during ripening (Gomez et al., 1997). It may thus be expected to help understand the effect of incorporating nisinproducing and/or debittering $L b$. casei strains in Cheddar cheese starter culture on proteolysis in the resulting cheeses. Light absorbance of peptides and amino acids in the water-soluble cheese extracts is usually measured at 214 and $280 \mathrm{~nm}$. Peptide bonds have much more light absorbance at 214 than at $280 \mathrm{~nm}$, while aromatic acids, their peptides and derivatives are usually detected at $280 \mathrm{~nm}$. Table 5 shows the evolution of total water-soluble peptide contents detected at 214 and $280 \mathrm{~nm}$ during ripening of control and experimental cheeses.

Total peptide content. The initial total peptide content measured at $214 \mathrm{~nm}$ did not significantly differ between NF and ISN cheeses, but was significantly lower for COM cheese. This does not directly mean that both NF and ISN cheeses had both the same concentrations of hydrophilic and hydrophobic peptides. The formation of several hydrophilic and hydrophobic peptides in ISN cheese was evident since the day of manufacture (Figure 1). Total peptide content present in the water- 
Table 4. Evolution of rheological parameters of experimental Cheddar cheeses.

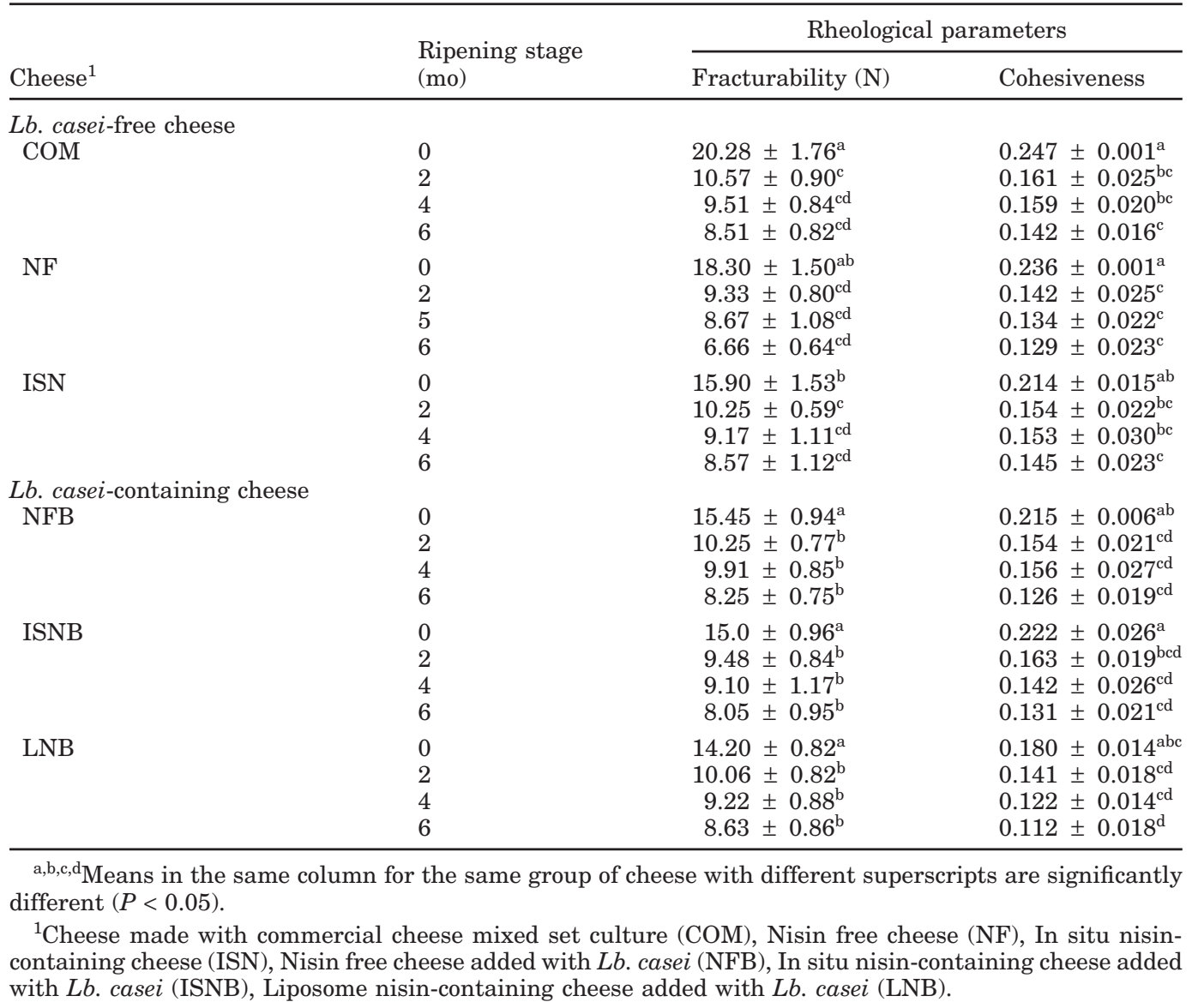

extract increased with cheese age depending on treatment (Table 5). Increased total peptide content in Cheddar cheese water-extract during ripening has also been reported by Lau et al. (1991). At 6 mo, COM and ISN cheeses accumulated significantly higher total watersoluble peptide content than NF cheese.

With added $L b$. casei, the total peptides content detected at d $0(214 \mathrm{~nm})$ was significantly lower than without, which may be due to the heat treatment applied to milk used for the production of $L b$. casei-containing cheeses (Kosikowski, 1951). This difference was less apparent after 2 mo of ripening. Cheeses containing Lb. casei and nisin Z, either produced in situ or encapsulated contained slightly higher initial amounts of total water-soluble peptide at $214 \mathrm{~nm}$ compared to their control cheese (NFB). The total peptide concentration in all three cheeses increased significantly up to $4 \mathrm{mo}$, after which there was little or no increase and no significant differences among them.

On the day of manufacture, NF and ISN cheeses contained significantly more amount total peptides $(280$ $\mathrm{nm}$ ) than the COM cheese. The effect of the nisin-producing strain on total peptide content became apparent at $4 \mathrm{mo}$, with ISN cheeses gaining significantly compared to NF cheese. The latter did not show any change over the first 4 mo of ripening, after which a noticeable decreased occurred, as for ISN cheese, although the final level was higher than in NF cheese. Decreases in total water-soluble peptides detected at $280 \mathrm{~nm}$, such as seen at 6 mo in NF and ISN cheeses, have been previously reported by Lau et al. (1991) who gave two possible explanations. First, peptides liberated early during ripening may contain more aromatic amino acids, which are removed preferentially by peptidases, leaving relatively high molecular weight peptides with fewer aromatic acids. Consequently, the amount of high molecular weight hydrophobic peptides detected at 214 $\mathrm{nm}$ increased, but that detected at $280 \mathrm{~nm}$ remained unchanged or decreased (Table 5). The second possibility is that proteins are hydrolyzed during aging to highly hydrophobic peptides, which are no longer water-soluble and not detected in the water-extract of 6mo-old cheeses. It may be assumed that aromatic amino acids are more abundant in such peptides. If so, it may be further assumed that neither of those mechanisms 
Table 5. Evolution of total area count of total water-soluble peptides during ripening of experimental Cheddar cheeses determined by reversed-phase HPLC at 214 and $280 \mathrm{~nm}$.

\begin{tabular}{|c|c|c|c|}
\hline \multirow[b]{2}{*}{ Cheese $^{1}$} & \multirow{2}{*}{$\begin{array}{l}\text { Ripening } \\
\text { stage } \\
\text { (mo) }\end{array}$} & \multicolumn{2}{|c|}{ Total count area $\left(\times 10^{7}\right)$} \\
\hline & & $214 \mathrm{~nm}$ & $280 \mathrm{~nm}$ \\
\hline \multicolumn{4}{|c|}{ Lb. casei-free cheese } \\
\hline \multirow[t]{4}{*}{ COM } & 0 & $7.0 \pm 0.09^{\mathrm{d}}$ & $1.60 \pm 0.01^{\mathrm{c}}$ \\
\hline & 2 & $11.2 \pm 0.05^{\mathrm{c}}$ & $2.20 \pm 0.01^{\mathrm{b}}$ \\
\hline & 4 & $17.0 \pm 0.04^{\mathrm{b}}$ & $2.40 \pm 0.04^{\mathrm{b}}$ \\
\hline & 6 & $19.2 \pm 0.03^{\mathrm{a}}$ & $2.80 \pm 0.08^{a}$ \\
\hline \multirow[t]{4}{*}{$\mathrm{NF}$} & 0 & $11.6 \pm 0.01^{\mathrm{c}}$ & $2.40 \pm 0.01^{\mathrm{b}}$ \\
\hline & 2 & $15.6 \pm 0.01^{\mathrm{b}}$ & $2.40 \pm 0.03^{\mathrm{b}}$ \\
\hline & 4 & $16.6 \pm 0.01^{\mathrm{b}}$ & $2.10 \pm 0.03^{\mathrm{b}}$ \\
\hline & 6 & $16.9 \pm 0.02^{\mathrm{b}}$ & $1.70 \pm 0.01^{\mathrm{c}}$ \\
\hline \multirow[t]{4}{*}{ ISN } & 0 & $11.7 \pm 0.01^{\mathrm{c}}$ & $2.20 \pm 0.08^{\mathrm{b}}$ \\
\hline & 2 & $12.5 \pm 0.04^{\mathrm{c}}$ & $1.90 \pm 0.06^{\mathrm{b}}$ \\
\hline & 4 & $18.2 \pm 0.02^{\mathrm{a}}$ & $3.60 \pm 0.02^{\mathrm{a}}$ \\
\hline & 6 & $18.6 \pm 0.01^{\mathrm{a}}$ & $2.40 \pm 0.02^{\mathrm{b}}$ \\
\hline \multicolumn{4}{|c|}{ Lb. casei-containing cheese } \\
\hline \multirow[t]{4}{*}{ NFB } & 0 & $6.1 \pm 0.01^{\mathrm{c}}$ & $1.60 \pm 0.05^{\mathrm{b}}$ \\
\hline & 2 & $14.4 \pm 0.02^{\mathrm{b}}$ & $1.60 \pm 0.03^{\mathrm{b}}$ \\
\hline & 4 & $15.6 \pm 0.02^{\mathrm{a}}$ & $2.20 \pm 0.03^{\mathrm{ab}}$ \\
\hline & 6 & $16.8 \pm 0.02^{\mathrm{a}}$ & $1.90 \pm 0.01^{\mathrm{ab}}$ \\
\hline \multirow[t]{4}{*}{ ISNB } & 0 & $6.7 \pm 0.06^{\mathrm{c}}$ & $1.10 \pm 0.05^{\mathrm{b}}$ \\
\hline & 2 & $13.9 \pm 0.01^{b}$ & $1.40 \pm 0.01^{\mathrm{b}}$ \\
\hline & 4 & $15.9 \pm 0.05^{\mathrm{a}}$ & $2.50 \pm 0.01^{\mathrm{a}}$ \\
\hline & 6 & $17.3 \pm 0.01^{\mathrm{a}}$ & $1.60 \pm 0.01^{\mathrm{b}}$ \\
\hline \multirow[t]{4}{*}{ LNB } & 0 & $7.1 \pm 0.01^{\mathrm{c}}$ & $1.30 \pm 0.03^{\mathrm{b}}$ \\
\hline & 2 & $14.1 \pm 0.02^{\mathrm{b}}$ & $1.20 \pm 0.03^{\mathrm{b}}$ \\
\hline & 4 & $15.7 \pm 0.02^{\mathrm{a}}$ & $1.70 \pm 0.02^{\mathrm{ab}}$ \\
\hline & 6 & $15.5 \pm 0.03^{\mathrm{a}}$ & $2.00 \pm 0.03^{\mathrm{a}}$ \\
\hline
\end{tabular}

${ }^{\mathrm{a}, \mathrm{b}, \mathrm{c}}$ Means in the same column for the same group of cheese with different superscripts are significantly different $(P<0.05)$.

${ }^{1}$ Cheese made with commercial cheese mixed set culture (COM), Nisin free cheese (NF), In situ nisincontaining cheese (ISN), Nisin free cheese added with $L b$. casei (NFB), In situ nisin-containing cheese added with $L b$. casei (ISNB), Liposome nisin-containing cheese added with Lb. casei (LNB).

is at work in COM cheese, since the increase in absorption at $280 \mathrm{~nm}$ was constant.

The initial amounts of total water-soluble peptides measured at $280 \mathrm{~nm}$ did not significantly differ among cheeses with added $L b$. casei and were close to those detected in COM cheese but lower than those detected in NF and ISN cheeses. During ripening, levels were relatively constant. As with cheese ISN, ISNB cheeses accumulated the highest peptide content at 4 mo but levels were significantly lower than in ISN cheese. At the end of ripening, the concentration in ISNB cheese was slightly lower than in NFB cheese and LNB cheeses.

Hydrophobic and hydrophilic peptides at 214 $\mathbf{n m}$. The evolution of hydrophilic and hydrophobic peptide concentration and ratio determined at 214 and 280 $\mathrm{nm}$ in the water-soluble extract during ripening of experimental cheeses is given in Table 6. Generally, the amount of both peptides detected at $214 \mathrm{~nm}$ increased as cheeses aged, indicating the continuous breakdown of casein and high molecular peptides. This is consistent with the results of Lau et al. (1991) who reported contin- uous increases at $214 \mathrm{~nm}$ during Cheddar cheese ripening. On the day of manufacture, NF and ISN cheeses contained significantly higher amounts of both types of peptide than COM cheese. Upon aging, the water soluble extract of ISN cheese contained slightly more peptides compared to NF cheese. Six-month-old ISN cheese accumulated a significantly higher concentration of hydrophilic peptides than NF and COM cheeses. Generally, higher hydrophilic peptide content in cheese water-soluble extract is correlated with more intense and more characteristic aged Cheddar flavor (Champion and Stanley, 1982). Levels of hydrophobic peptides determined at 6 mo did not significantly differ among NF, ISN and COM cheeses. The hydrophobic:hydrophilic ratio differed significantly depending on treatment and age. Significantly higher ratios were obtained for NF and COM cheeses compared to ISN cheese. This may be due to some activity in the nisinogenic mixed culture that produce more hydrophilic than hydrophobic peptides. The differences in peptide ratios may be correlated with flavor differences and intensities. During 

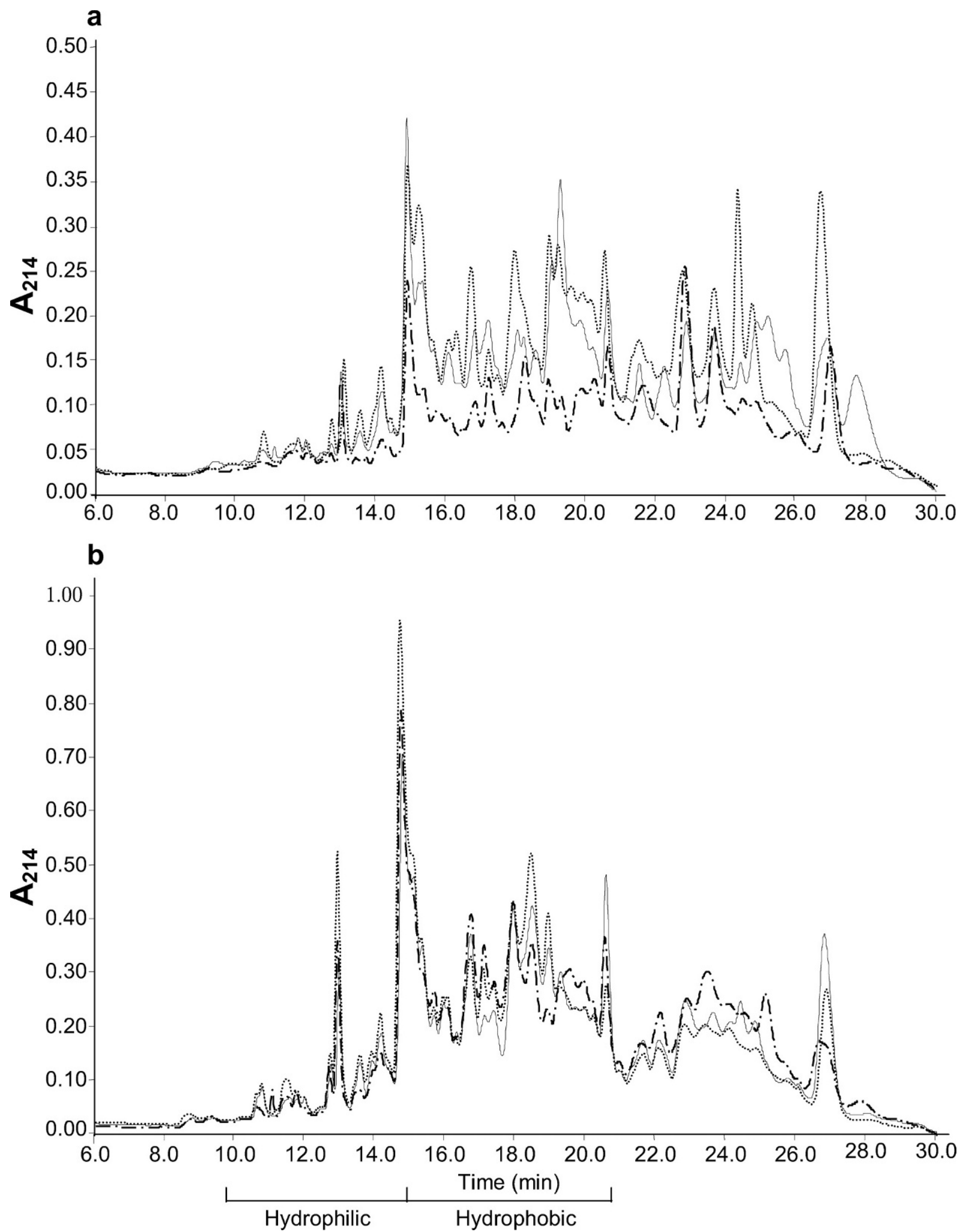

Figure 1. HPLC separation of peptides in the water-soluble fraction of fresh (a) and six-mo-old Cheddar cheeses (b) with detection at a wavelength of $214 \mathrm{~nm}\left(\mathrm{~A}_{214}\right)$. (-- - $)$ : Cheese made with commercial starter culture (COM cheese); (—): Cheese made with selected starter (NF cheese) and $(\cdots \cdots)$ : Cheese made with nisinogenic starter culture (ISN cheese). 
Table 6. Evolution of area count $\left(\times 10^{7}\right)$ of hydrophilic and hydrophobic peptides and their ratio in the water-soluble extract of experimental Cheddar cheeses determined by reversed-phase HPLC at 214 and $280 \mathrm{~nm}$.

\begin{tabular}{|c|c|c|c|c|c|c|c|}
\hline Cheese $^{1}$ & $\begin{array}{l}\text { Ripening stage } \\
\text { (mo) }\end{array}$ & \multicolumn{3}{|c|}{$214 \mathrm{~nm}$} & \multicolumn{3}{|c|}{$280 \mathrm{~nm}$} \\
\hline \multicolumn{8}{|c|}{ Lb. casei-free cheese } \\
\hline \multirow{3}{*}{ COM } & 2 & $2.18 \pm 0.20^{\mathrm{d}}$ & $4.33 \pm 0.30^{\mathrm{e}}$ & $1.99 \pm 0.10^{\mathrm{e}}$ & $0.35 \pm 0.03^{\mathrm{c}}$ & $1.50 \pm 0.01^{b}$ & $4.28 \pm 0.40^{\mathrm{c}}$ \\
\hline & 4 & $3.52 \pm 0.05^{\mathrm{c}}$ & $7.15 \pm 0.04^{\mathrm{bc}}$ & $2.03 \pm 0.04^{\mathrm{e}}$ & $0.56 \pm 0.03^{\mathrm{b}}$ & $1.55 \pm 0.01^{\mathrm{b}}$ & $2.74 \pm 0.10^{\mathrm{e}}$ \\
\hline & 6 & $4.27 \pm 0.05^{\mathrm{b}}$ & $8.04 \pm 0.09^{\mathrm{ab}}$ & $1.88 \pm 0.04^{\mathrm{f}}$ & $0.71 \pm 0.01^{\mathrm{a}}$ & $1.54 \pm 0.09^{b}$ & $2.18 \pm 0.10^{\mathrm{f}}$ \\
\hline \multirow{2}{*}{$\mathrm{NF}$} & 4 & $3.63 \pm 0.02^{\mathrm{c}}$ & $7.40 \pm 0.10^{\mathrm{ab}}$ & $2.04 \pm 0.02^{\mathrm{e}}$ & $0.35 \pm 0.02^{\mathrm{c}}$ & $1.13 \pm 0.10^{\mathrm{c}}$ & $3.23 \pm 0.10^{\mathrm{d}}$ \\
\hline & 6 & $3.97 \pm 0.05^{\mathrm{c}}$ & $8.80 \pm 0.05^{\mathrm{a}}$ & $2.21 \pm 0.05^{\mathrm{d}}$ & $0.45 \pm 0.02^{\mathrm{b}}$ & $0.76 \pm 0.04^{\mathrm{d}}$ & $1.68 \pm 0.02^{\mathrm{g}}$ \\
\hline \multirow[t]{4}{*}{ ISN } & 0 & $1.52 \pm 0.07^{\mathrm{e}}$ & $5.93 \pm 0.01^{\mathrm{c}}$ & $3.89 \pm 0.20^{\mathrm{b}}$ & $0.32 \pm 0.01^{\mathrm{c}}$ & $1.64 \pm 0.02^{\mathrm{b}}$ & $5.11 \pm 0.20^{\mathrm{b}}$ \\
\hline & 2 & $1.58 \pm 0.05^{\mathrm{e}}$ & $5.88 \pm 0.05^{\mathrm{c}}$ & $3.72 \pm 0.05^{\mathrm{b}}$ & $0.29 \pm 0.01^{\mathrm{c}}$ & $1.15 \pm 0.08^{\mathrm{c}}$ & $4.00 \pm 0.20^{\mathrm{c}}$ \\
\hline & 4 & $4.31 \pm 0.10^{\mathrm{b}}$ & $7.95 \pm 0.05^{\mathrm{ab}}$ & $1.84 \pm 0.07^{\mathrm{f}}$ & $0.61 \pm 0.06^{\mathrm{ab}}$ & $2.30 \pm 0.04^{\mathrm{a}}$ & $3.79 \pm 0.30^{c}$ \\
\hline & 6 & $5.17 \pm 0.02^{\mathrm{a}}$ & $8.21 \pm 0.02^{\mathrm{a}}$ & $1.59 \pm 0.01^{\mathrm{g}}$ & $0.65 \pm 0.01^{\mathrm{a}}$ & $1.44 \pm 0.06^{\mathrm{b}}$ & $2.20 \pm 0.08^{f}$ \\
\hline \multicolumn{8}{|c|}{$L b$. casei-containing cheese } \\
\hline \multirow[t]{4}{*}{ ISNB } & 0 & $0.81 \pm 0.05^{\mathrm{e}}$ & $3.47 \pm 0.05^{\mathrm{d}}$ & $4.27 \pm 0.05^{\mathrm{b}}$ & $0.33 \pm 0.01^{\mathrm{a}}$ & $0.66 \pm 0.01^{b}$ & $2.01 \pm 0.07^{\mathrm{g}}$ \\
\hline & 2 & $2.47 \pm 0.04^{\mathrm{c}}$ & $5.95 \pm 0.01^{\mathrm{c}}$ & $2.40 \pm 0.05^{\mathrm{c}}$ & $0.19 \pm 0.03^{\mathrm{d}}$ & $0.84 \pm 0.01^{b}$ & $4.41 \pm 0.70^{b}$ \\
\hline & 4 & $3.61 \pm 0.05^{b}$ & $7.39 \pm 0.05^{\mathrm{ab}}$ & $2.05 \pm 0.05^{\mathrm{d}, \mathrm{e}}$ & $0.39 \pm 0.05^{\mathrm{a}}$ & $1.53 \pm 0.03^{\mathrm{a}}$ & $3.95 \pm 0.04^{\mathrm{d}}$ \\
\hline & 6 & $4.52 \pm 0.02^{\mathrm{a}}$ & $7.69 \pm 0.02^{\mathrm{a}}$ & $1.70 \pm 0.01^{\mathrm{f}}$ & $0.46 \pm 0.02^{\mathrm{a}}$ & $0.86 \pm 0.01^{b}$ & $1.88 \pm 0.10^{\mathrm{g}}$ \\
\hline \multirow[t]{4}{*}{ LNB } & 0 & $0.80 \pm 0.01^{\mathrm{e}}$ & $3.64 \pm 0.02^{\mathrm{d}}$ & $4.58 \pm 0.05^{b}$ & $0.33 \pm 0.01^{\mathrm{a}}$ & $0.74 \pm 0.01^{b}$ & $2.23 \pm 0.10^{f}$ \\
\hline & 2 & $2.56 \pm 0.08^{\mathrm{d}}$ & $6.72 \pm 0.01^{\mathrm{b}}$ & $2.61 \pm 0.20^{\mathrm{c}}$ & $0.17 \pm 0.01^{\mathrm{d}}$ & $0.66 \pm 0.07^{b}$ & $3.85 \pm 0.10^{\mathrm{d}}$ \\
\hline & 4 & $3.48 \pm 0.05^{b}$ & $6.94 \pm 0.05^{\mathrm{b}}$ & $1.99 \pm 0.05^{\mathrm{e}}$ & $0.27 \pm 0.03^{c}$ & $1.02 \pm 0.02^{\mathrm{a}}$ & $3.77 \pm 0.30^{\mathrm{d}}$ \\
\hline & 6 & $3.75 \pm 0.05^{\mathrm{b}}$ & $7.14 \pm 0.05^{\mathrm{b}}$ & $1.90 \pm 0.05^{\mathrm{e}}$ & $0.34 \pm 0.02^{\mathrm{a}}$ & $1.10 \pm 0.04^{\mathrm{a}}$ & $3.24 \pm 0.08^{\mathrm{e}}$ \\
\hline
\end{tabular}

Means in the same column for the same group of cheese with different superscripts are significantly different $(P<0.05)$.

${ }^{1}$ Cheese made with commercial cheese mixed set culture (COM), Nisin free cheese (NF), In situ nisin-containing cheese (ISN), Nisin free cheese added with $L b$. casei (NFB), In situ nisin-containing cheese added with $L b$. casei (ISNB), Liposome nisin-containing cheese added with Lb. casei (LNB).

ripening, the peptide ratio in all cheeses tends to decrease as ripening progressed (Lau et al., 1991).

For Lb. casei-containing cheeses, the concentration of hydrophilic and hydrophobic peptides was slightly lower than those estimated in the first group of cheeses, which could be again attributed to the heat treatment applied to cheese milk. The evolution of hydrophilic and hydrophobic peptides during ripening was similar to that observed for the first group of cheeses. On the day of manufacture, ISNB and LNB cheeses had higher hydrophilic peptide content than NFB-cheese, while levels of hydrophobic peptides did not significantly differ. This may be due to autolysis of a nisin-sensitive Lactococcus sp. population caused by nisin released during cheese production. A previous study indicated that approximately $11 \%$ of initially encapsulated nisin $\mathrm{Z}$ may be released in milk subjected to the Cheddar cheese temperature cycle (Laridi et al., 2003). At 6 mo, ISNB cheese accumulated higher concentrations of hydrophilic peptides compared to NFB and LNB cheeses, while hydrophobic peptides did not significantly differ between NFB and ISNB cheeses. During ripening, LNB cheese showed peptide patterns very close to those for
NFB cheese. As in the first group of cheeses, the hydrophobic:hydrophilic peptide ratio gradually decreased as cheeses aged, and NFB cheese had the highest ratio on the day of manufacture. Peptide ratios did not significantly differ at 2 or 4 mo but differences became significant at 6 mo as ISNB and LNB cheeses exhibited a significantly lower ratio than NFB cheese. This may be due to increased hydrophilic peptide generation in ISNB and LNB cheeses rather than to reduced production of hydrophobic peptides. The difference in the evolution of hydrophilic and hydrophobic peptides and their ratio between LNB and ISNB cheeses may be linked to nisin molecules or the nisin-producing strain. Rapid release of liposome-entrapped nisin $\mathrm{Z}$ may be necessary to induce autolysis during the first part of ripening, while the nisin-producing strain may participate in cheese proteolysis by lysis of a nisin-sensitive subpopulation of starter lactococci following nisin production and/or by its own autolysis.

Hydrophobic and hydrophilic peptides at 280 $\mathbf{n m}$. The amount of hydrophilic peptides detected at $280 \mathrm{~nm}$ in the water-extract of $L b$. casei-free cheeses increased slightly, with few exceptions, throughout rip- 
ening (Table 6). Commercial starter culture (COM) appeared to produce more hydrophilic peptides than selected starter culture (NF). Compared to selected culture alone, the effect of the nisin-producing strain (ISN) on $280 \mathrm{~nm}$-hydrophilic peptide content became significant at 4 and 6 mo. At 6 mo, there were no significant differences in $280 \mathrm{~nm}$-hydrophilic peptides levels between ISN and COM cheeses. In contrast, the concentration of hydrophilic peptides fluctuated considerably during aging of cheeses with added $L b$. casei. The concentration of these peptides reached a maximum at 4 mo in both NFB and ISNB cheeses and at 6 mo in LNB cheese. This is in contrast with the continuous increase in hydrophilic peptides in the water-soluble fraction detected at $214 \mathrm{~nm}$, which may be due to differences in light absorbance characteristics between peptide bonds and aromatic amino acids at the two wavelengths.

The amount of hydrophobic peptides detected at 280 $\mathrm{nm}$ in COM cheese remained relatively constant during ripening. The amount of these peptides in 0-d-old NF and ISN cheeses was higher than that detected in COM cheese. The evolution of hydrophobic peptides in NF and ISN cheeses was considerably different during cheese ripening. In NF cheese, there was a gradual decrease in hydrophobic peptide content with aging, indicating the continued breakdown of aromatic acidscontaining peptides. However, the hydrophobic peptide content decreased in ISN cheese at 2 mo, increased at $4 \mathrm{mo}$ and then decreased. This is in contrast to the continued increase in hydrophobic peptide concentration detected at $214 \mathrm{~nm}$. Lau et al. (1991) reported that the concentration of hydrophobic peptides detected at $280 \mathrm{~nm}$ present in Cheddar cheese water extract reached a maximum at 3 mo and then decreased. This may be due to degradation of hydrophobic peptides formed during the first part of ripening and/or the formation of highly hydrophobic peptides and no longer water-soluble. At $6 \mathrm{mo}$, the concentration of $280 \mathrm{~nm}$ hydrophobic peptides was in the order COM > ISN > NF cheese. The appearance of bitter off-flavor in cheese is strongly correlated with the level of hydrophobic peptides absorbing at $280 \mathrm{~nm}$ in the cheese water-soluble extract (Gomez et al., 1997).

Cheeses with added $L b$. casei exhibited a trend of hydrophobic peptide evolution similar to that of the $L b$. casei-free cheeses but with slightly lower peptide levels. The highest concentration of these peptides was detected at $4 \mathrm{mo}$ in NFB and ISNB cheeses and at 6 mo in LNB cheese, while 6-mo-old ISNB cheese exhibited the lowest content. This cheese also accumulated the highest level of hydrophilic peptides detected at 214 $\mathrm{nm}$ at $6 \mathrm{mo}$ of ripening. This may indicate a synergistic on hydrophobic peptides reduction in Cheddar cheese obtainable by incorporating $L b$. casei-casei L2A and Lac. diacetylatis UL719 into the starter culture.

The HPLC chromatographic profiles at $280 \mathrm{~nm}$ of all cheeses were quite similar and showed the presence of a major peak in the hydrophobic region with retention time of $19 \mathrm{~min}$. The intensity of this peak was much lower in cheeses with added $L b$. casei than $L b$. caseifree cheeses. The intensity of this peak on the day of manufacture was much higher in NFB cheese, followed by LNB and ISNB cheeses (Figure 2a) and appeared to decrease gradually during ripening coinciding with increasing intensity of a peak in the hydrophilic region with a retention time of 13 min (Figure 2b). At 6 mo, the intensity of the latter peak was much higher in ISNB cheese than in NFB and LNB cheeses.

The hydrophobic:hydrophilic peptide ratios determined at $280 \mathrm{~nm}$ in the water extracts during cheese ripening are given in Table 6 . Values obtained in this study for this ratio are considerably lower than those reported by Lau et al. (1991) for Cheddar cheese made from raw or pasteurized milk. At $0 \mathrm{~d}$, ISN cheese exhibited peptide ratio close to that for COM cheese, but significantly lower than for NF cheese. At $6 \mathrm{mo}$, the peptide ratio in ISN cheese became higher than that in NF cheese and remained close to COM cheese. This is in contrast with the peptide ratio determined at 214 $\mathrm{nm}$, where 6-mo-old ISN cheese exhibited the lowest peptide ratio compared to $\mathrm{NF}$ and COM cheeses. This is probably due to differences in light absorbance of certain peptides at the two wavelengths possibly greater accumulation of aromatic-containing peptides in ISN than in NF cheese.

For $L b$. casei containing cheeses, the peptide ratios at $280 \mathrm{~nm}$ in LNB and ISNB cheeses were significantly lower than in NFB cheese at the beginning of ripening, as was the case for ISN and NF cheeses. Both ISNB and LNB cheeses accumulated higher final hydrophilic peptide concentration and equal or lower hydrophobic peptide concentration than did NFB cheese. The peptide ratio increased significantly at 2 mo in NFB cheese and then decreased. At 6 mo, ISNB cheese showed the lowest peptide ratio, suggesting that the nisin-producing strain may have greater impact than nisin-containing liposomes on Cheddar cheese peptide balance.

\section{Sensory Evaluation}

The grading system was basically directed to detect flavor defects and grade cheeses according to their overall quality rather than determination of flavor intensity (Trépanier et al., 1991). On this basis, cheeses were classified in the following order: NFB and LNB $>\mathrm{NF}>$ ISNB > ISN > COM cheese. The most frequently recognized taste $(n=5)$ in cheeses with added nisinogenic 

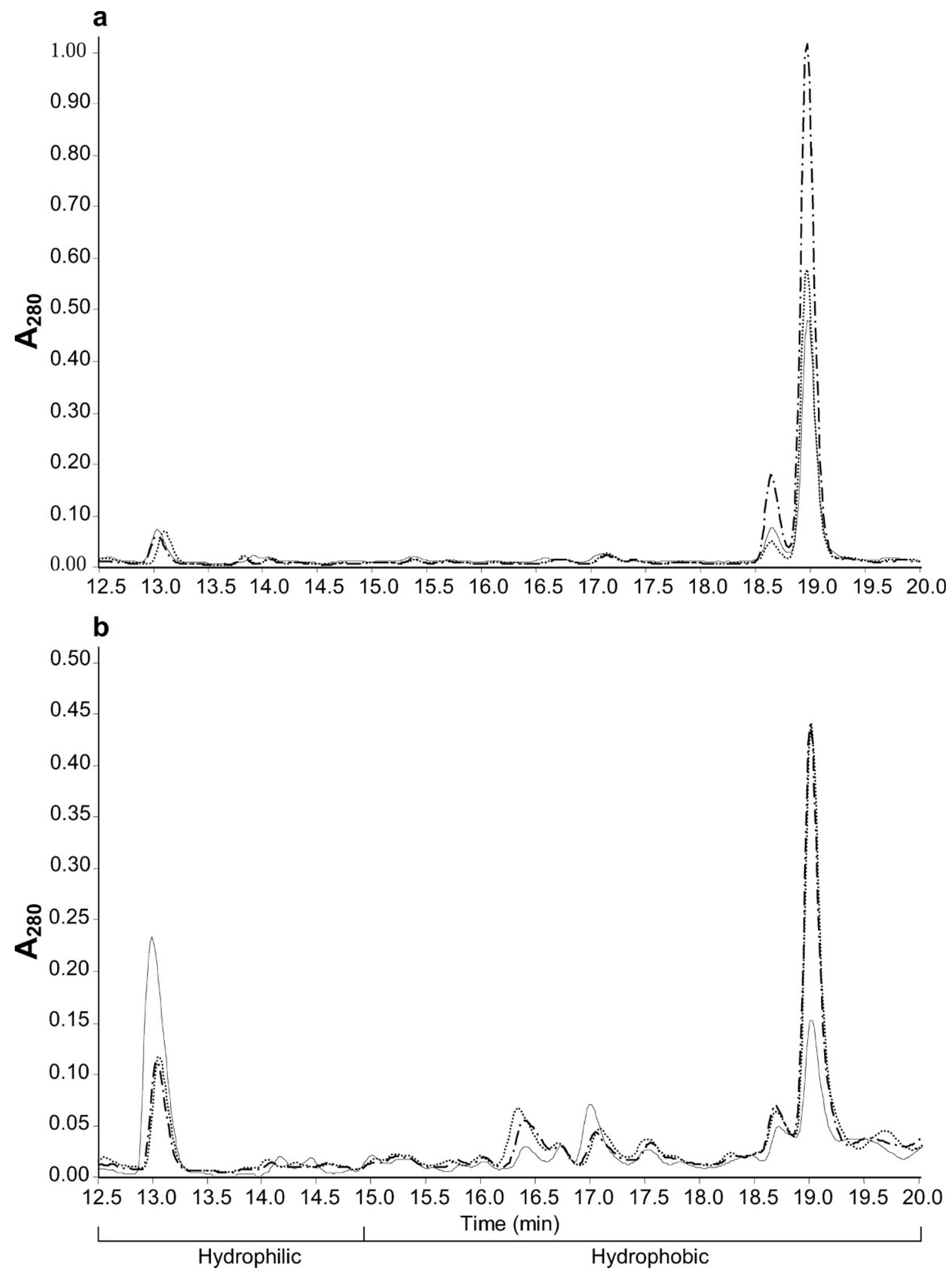

Figure 2. HPLC separation of peptides in the water-soluble fraction of fresh (a) and six-mo-old Cheddar cheeses (b) with detection at a wavelength of $280 \mathrm{~nm}\left(\mathrm{~A}_{280}\right)$. (-- —): Lb. casei containing cheese made with selected starter culture (NFB cheese); (—): Lb. casei containing cheese made with nisinogenic starter (ISNB cheese) and $(\cdots \cdots): L b$. casei containing cheese made with selected starter culture and added with nisin $\mathrm{Z}$ containing-liposomes(LNB cheese). 
strain (ISN and ISNB cheeses) was acidic taste, which was more evident in ISN than in ISNB cheese. Both had significantly higher TA values at 6 mo than their control cheeses (Table 2).

A bitter off-flavor was recognized $(n=5)$ in all but one cheese and was much more pronounced in $L b$. caseifree cheeses than $L b$. casei containing cheeses, indicating the debittering activity of $L b$. casei. Although, this defect was not detected in cheese made with commercial starter, another defect described as unclean or unpleasant was cited $(\mathrm{n}=5)$. The presence of bitter off-flavor among experimental cheeses made in this study may be due to the starter culture, which was selected for their nisin-tolerance characteristics and high acidifying properties. It is believed that cheese starter culture has a distinct role in determining cheese flavor intensity and quality (Pritchard and Coolbear, 1993). Selection of a nisinogenic mixed starter culture must take into consideration several criteria including proteolytic activity and debittering effects. The incorporation of a nisin-producing strain with debittering strains may thus improve cheese flavor quality (Wouters et al., 2002). The intensity of bitter taste in our cheeses with added nisin-producing strain was much less pronounced than in nisin-free cheeses. This characteristic coincided with the reduced intensity of a peak eluting at $19 \mathrm{~min}$ during HPLC runs with detection at $280 \mathrm{~nm}$.

The improved overall quality of $L b$. case $i$ containing cheeses (NFB and LNB cheeses) found in this study confirm previous studies (Trépanier et al., 1991). Sensory analysis also indicated that the addition of $L b$. casei strain enhanced only the flavor quality and not the flavor intensity. This result is consistent with the findings of El Abboudi (1990). Increased levels of methyl ketone production in $L b$. casei-containing cheese enhanced only the flavor quality. On the other hand, there was no detectable difference in flavor between liposome containing cheese (LNB cheese) and its control NFB cheese. This was consistent with results obtained for proteolysis, textural and RP-HPLC analyse (no significant difference at $6 \mathrm{mo}$ ). The absence of major sensory defects in liposome containing cheese may be considered a positive result combined with technological and microbiological data (Benech et al., 2002a; Benech et al., 2002b). Our data provide motivation to use nisin containing-liposomes in cheese manufacture to ensure safety without affecting production or ripening processes.

\section{CONCLUSION}

This study has demonstrated that the incorporation of Lac. diacetylactis UL719, a nisin Z producer, into Cheddar cheese starter culture leads to proteolysis measurable in terms of trichloroacetic acid and phosphotungstic acid soluble nitrogen, but not significantly affecting cheese rheological characteristics. Lac. diacetylactis UL719 may also change peptide concentration and hydrophobic:hydrophilic peptide ratio in cheese water-extract. Enzymatic capabilities of Lac. diacetylactis UL719 cells or autolysis of a nisin-sensitive subpopulation of our selected starter lactococci may be responsible for proteolysis in cheese containing this strain. The use of $L b$. casei L2A as cheese secondary microflora improves flavor quality and appears to attenuate a bitter defect reported for cheeses without $L b$. casei. In order to maximize the benefits of incorporating a nisinproducing strain into a cheese starter culture, a selection of mixed culture using multiple criteria, such as higher debittering activity, moderate nisin-tolerance and acceptable acidification properties, is required to obtain cheese with higher flavor intensity and quality. A single-criterion selection could easily interfere with cheese-making process and lead to the formation of undesirable flavors. The incorporation of nisin-containing liposomes into Cheddar cheese milk did not appear to affect cheese proteolysis and rheological attributes and may offer advantage over nisin-producing strains. This system would be a valuable tool to ensure cheese safety and to control undesirable bacteria without affecting cheese sensory, biochemical and textural attributes.

\section{ACKNOWLEDGMENTS}

This research was carried out within the program of the Canadian Research Network on Lactic Acid Bacteria, supported by the National Sciences and Engineering Research Council of Canada, Agriculture and Agri-Food Canada, Novalait Inc., The Dairy Farmers of Canada, Rosell-Lallemand Inc., and by the Fond pour les Chercheurs et l'Avancement de la Recherche from the Province of Quebec.

\section{REFERENCES}

Association of Official Analytical Chemists. 1990. Official Methods of Analysis. Vol. I. 15th ed. AOAC, Arlington, VA.

Aston, J. W., P. A. Grieve, I. G. Durward, and J. R. Dulley. 1983. Proteolysis and flavor development in Cheddar cheese subjected to accelerated ripening treatments. Aust. J. Dairy Technol. 38:59-63.

Bartels, H. J., M. E. Johnson, and N. F. Olson. 1987. Accelerated ripening of Gouda cheese: II. Effect of freeze-shocked Lactobacillus helveticus on proteolysis and flavor development. Milchwissenschaft 42:139-144.

Benech, R. -O., E. E. Kheadr, R. Laridi, C. Lacroix, and I. Fliss. 2002a. Inhibition of Listeria innocua in Cheddar cheese by addition of nisin $\mathrm{Z}$ in liposomes or in situ production by mixed culture. Appl. Environ. Microbiol. 68:3683-3690.

Benech, R. -O., E. E. Kheadr, C. Lacroix, and I. Fliss. 2002b. Antibacterial activities of nisin Z encapsulated in liposomes or produced in situ by mixed culture during Cheddar cheese ripening. Appl. Environ. Microbiol. 68: 5607-5619. 
Bouksaim, M., C. Lacroix, P. Audet, and R. E. Simard. 2000. Effect of mixed starter composition on nisin $\mathrm{Z}$ production by Lactococcus lactis ssp. lactis biovar. diacetylactis UL719 during production and ripening of Gouda cheese. Int. J. Food Microbiol. 59:141-156.

Buyong, N., J. Kok, and J. B. Luchansky. 1998. Use of genetically enhanced, pediocin-producing starter culture, Lactococcus lactis ssp. lactis MM217, to control Listeria monocytogenes in Cheddar cheese. Appl. Environ. Microbiol. 64:4842-4845.

Champion, H. M., and D. W. Stanley. 1982. HPLC separation of bitter peptides from Cheddar cheese. Can. Inst. Food Sci. Technol. 15:283-288.

Daoudi, L., C. Turcotte, C. Lacroix, and I. Fliss. 2001. Production and characterization of anti-nisin Z monoclonal antibodies: suitability for distinguishing active from inactive forms through a competitive enzyme immunoassay. Appl. Microbiol. Biotechnol. $56: 114-119$

El Abboudi, M. 1990. The production of neutral volatile compound in Cheddar cheeses during accelerated ripening. M.S. Thesis. Laval Univ., Québec, Canada.

Fox, P. F. 1989. Acceleration of Cheddar cheese ripening. J. Food. Biotechnol. 2:133-185.

Gomez, M. J., S. Garde, P. Gaya, M. Medina, and M. Numez. 1997. Relationship between level of hydrophobic peptides and bitterness in cheese made from pasteurized and raw milk. J. Dairy Res. 64:289-297.

Gripon, J., N. Desmazeaud, D. Le Bars, and J. Bergere. 1975. Étude du rôle des microorganismes et des enzymes au cours de la maturation des fromages. II. Influence de la pressure commerciale. Lait 548:502-516.

Hurst, A. 1981. Nisin. Adv. Appl. Microbiol. 27:85-123.

International Dairy Federation. 1991. Rheological and fracture properties of cheese. IDF Bulletin 268.

International Dairy Federation.1993. Milk determination of nitrogen content. IDF standard no-20B.

Kempler, G. M., and L. L. McKay. 1980. Improved medium for detection of citrate fermenting Streptococcus lactis ssp. diacetylactis. Appl. Environ. Microbiol. 4:926-927.

Kheadr, E. E., J. C. Vuillemard, and S. A. El Deeb. 2000. Accelerated Cheddar cheese ripening with encapsulated proteases. Int. J. Food Sci. and Technol. 35:483-495.

Kheadr, E. E., J. C. Vuillemard, and S. A. El Deeb. 2002. Acceleration of cheese lipolysis by using liposomes-entrapped lipases. J. Food Sci. 67:485-492.

Kosikowski, F. V. 1951. The liberation of free amino acids in raw and pasteurized milk Cheddar cheese during ripening. J. Dairy Sci. 34:235-248.

Kosikowski, F. V. 1982. Cheddar cheese. Cheese and Fermented Milk Foods. 3rd ed. F. V. Kosikowski, ed. F. V. Kosikowski and Assoc., New York, NY.
Kuchroo, C. N., and P. F. Fox. 1982. Soluble nitrogen in Cheddar cheese: comparison of extraction procedures. Milchwissenschaft 37:331-335.

Laridi, R., E. E. Kheadr, R. -O. Benech, J. C. Vuillemard, C. Lacroix, and I. Fliss. 2003. Liposome encapsulated nisin Z: optimization, stability and release during milk fermentation. Int. Dairy J. 13:325-336.

Lau, K. Y., D. M. Barbano, and R. R. Rasmussen. 1990. Influence of pasteurization on fat and nitrogen recoveries and Cheddar cheese yield. J. Dairy Sci. 73:561-570.

Lau, K. Y., D. M. Barbano, and R. R. Rasmussen.1991. Influence of pasteurization of milk on protein breakdown in Cheddar cheese during aging. J. Dairy Sci. 74:727-740.

Lin, J., I. Jean, H. Roberts and G. Milliken. 1987. Effect of commercial food grade enzymes on proteolysis and textural changes in granular Cheddar cheese, J. Food Sci. 52:620-625.

Maisner-Patin, S., N. Deschamps, S. R. Tatini and J. Richard. 1992. Inhibition of Listeria monocytogenes in Camembert cheese made with nisin-producing starter. Lait 72:249-263.

Mazzotta, A. S., A. D. Crandall, and T. J. Montville. 1997. Nisin resistance in Clostridium botulinum spores and vegetative cells. Appl. Environ. Microbiol 63:2654-2659.

Morgan, S., R. P. Ross, and C. Hill. 1997. Increasing starter cell lysis in Cheddar cheese using a bacteriocin-producing adjunct. J. Dairy Sci. 80:1-10.

Pritchard, G., and T. Coolbear. 1993. The physiology and biochemistry of the proteolytic system of lactic acid bacteria. FEMS Microbiol. Rev. 21:179-206.

Rada, V., and J. Dlabal. 1998. Susceptibility of bifidobacteria to nisin. Lett. Appl. Microbiol. 26:123-125.

Roberts, R. F., and E. A. Zottola. 1993. Shelf-life of pasteurized process cheese spreads made from Cheddar cheese manufactured with a nisin-producing starter culture. J. Dairy Sci. 76:1829-1836.

Rodriguez, J. M. 1996. Review: Antimicrobial spectrum, structure, properties and mode of action of nisin, a bacteriocin produced by Lactococcus lactis. Food Sci. Technol. 2:61-68.

Tan, P. S. T., M. Chapot-Chartier, K. M. Pos, M. Rousseau, M. Boquien, J. Gripon, and W. N. Konings. 1992. Localization of peptidases in Lactococci. Appl. Environ. Microbiol. 58:285-290.

Trépanier, G., R. E. Simard, and B. H. Lee. 1991. Effect of added lactobacilli on composition and texture of Cheddar cheese during accelerated maturation. J. Food Sci. 56:695-700.

Wouters, J. T. M., E. H. E. Ayad, J. Hugenholtz, and G. Smit. 2002. Microbes from raw milk for fermented dairy products. Int. Dairy J. 12:91-109.

Zottola, E. A., T. L. Yessi, D. B. Ajao, and R. F. Roberts. 1994. Utilization of Cheddar cheese containing nisin as an antimicrobial agent in other foods. Int. J. Food Microbiol. 24:227-238. 